\title{
Nematicidal activity of essential oils of medicinal plants
}

\author{
Olexandra Boyko ${ }^{1}$, Viktor Brygadyrenko ${ }^{2 *}$
}

${ }^{1}$ Dnipro State Agrarian and Economic University, Sergiy Efremov st., 25, Dnipro, 49000, Ukraine

${ }^{2}$ Oles Honchar Dnipro National University, Gagarin av., 72, Dnipro, 49010, Ukraine

\begin{abstract}
Boyko, O., Brygadyrenko, V., 2021. Nematicidal activity of essential oils of medicinal plants. Folia Oecologica, 48 (1): 42-48.

We studied the effect of essential oils from Picea abies (Linnaeus) H. Karsten., 1881, Cinnamomum verum J. Pres1, 1825, Melaleuca alternifolia (Maiden \& Betche) Cheel, 1925, Citrus paradisi Macfadyen, 1830, Rosmarinus officinalis Linnaeus, 1753, Citrus aurantiifolia (Christmann) Swingle, 1913, Syzygium aromaticum (L.) Merrill \& Perry, 1939, Pterocarpus santalinus Linnaeus filius, 1782, Pelargonium graveolens L'Héritier, 1789, Eucalyptus globulus Labillardière, 1861, Juniperus communis Linnaeus, 1753, Piper cubeba L.f., 1781, Calendula officinalis L., 1753, Laurus nobilis Linnaeus, 1753, Lavandula angustifolia Miller, 1768 and Citrus sinensis (Linnaeus) Osbeck (pro. sp.) on vitality of free-living larvae of Strongyloides papillosus (Wedl, 1856) and Haemonchus contortus (Rudolphi, 1803) Cobb, 1898, and also survivability of eggs of Ascaris suum (Goeze, 1782) under in vitro conditions. The most notable nematicidal properties belong to $0.5 \%$ water emulsion of essential oils from C. verum and S. aromaticum: we observed $100 \%$ mortality of larvae of S. papillosus $\mathrm{L}_{1-3}$ and $H$. contortus $\mathrm{L}_{3}$.
\end{abstract}

Keywords

eggs, essential oils, flavourings, larvae, nematodes, mortality

\section{Introduction}

Among helminths of cattle, as well as wild ungulates, quite often recorded species are Strongyloides papillosus (Wedl, 1856) and representatives of Strongylata order. In swine breeding complexes and wild hogs in natural ecosystems, Ascaris suum (Goeze, 1782) dominates. Diseases they cause lead to big economic losses for farmers. Global need for the transition to non-chemical (organic) agriculture has given an impulse to reducing the use of veterinary preparations of synthetic origin and developing new plant-based preparations. All this has stimulated the use of natural and food additives which are identical to natural ones with anthelmintic, insecticidal, acaricidal, and antiprotozoal properties. Part of this research is focused on the effect of aqueous and alcohol extracts of medical plants on vitality of parasites in the environment (Boyko and Brygadyrenko, 2016, 2018, 2019a, 2019b; ZAZHARSKa et al., 2018; PALCHYKov et al., 2019).

Currently, data on use of essential oils from medicinal plants against different stages of parasites and agricultural pests are appearing with increasing frequency. These oils are applied in different concentrations, both in vitro and in vivo (KWEKA et al., 2011, 2012; REY-VALEIRÓN et al., 2017; Chen et al., 2019; Martynov et al., 2019a, 2019b; Zhou et al., 2019). Most often research focuses on mortality of parasites after exposing them to solutions of essential oils with exposure ranging 24-72 h. Lethal concentrations of essential oils, as well as exposure to their effective action against insects and Acari pests of agriculture and ectoparasites have been studied. The objective of this study was the determination of vitality of nematode larvae

*Corresponding author: e-mail: brigad@ua.fm 
of ruminants, and also eggs of nematodes of swine under the influence of essential oils from medicinal plants.

\section{Materials and methods}

The studies were performed at the Department of Parasitology and Veterinary-Sanitary Expertise of the Dnipro State Agro-Economic University. In the experiment, we used first- to third-stage larvae of the nematode of ruminants $S$. papillosus (rhabditiform first and second non-infective stages, filariform infective third stage), $H$. contortus at the third stage (infective), and also immature (without a developed larva) eggs of swine nematode A. suum. Larvae and eggs were identified by morphological features (VAN WYK et al., 2004, 2013; ZAJAC et al., 2011). Parasitological surveys for detecting eggs of nematodes were performed using the McMaster method. Identification of larvae was made by cultivation in a thermostat at the temperature of $24{ }^{\circ} \mathrm{C}$ over 8 days. For this purpose, the excrement of small ruminants (by $10 \mathrm{~g}$ ) was put into Petri dishes, which were then put into the thermostat. The samples in the thermostat were moistened every $24 \mathrm{~h}$. Larvae of $S$. papillosus at different stages were observed after $24-72 \mathrm{~h}, \mathrm{H}$. contortus at the third stage after 8 days. The surveys of excrement for presence of nematodes were made using the Bermann method.

After cultivation of the biomaterial, the larvae in normal saline $(4 \mathrm{~mL})$ in test tubes $(10 \mathrm{~mL})$ were centrifuged at 1,500 rtp over $4 \mathrm{~min}$. The sediment with larvae was by $0.1 \mathrm{~mL}$ (average 70-110 larvae) put into plastic test tubes of $1.5 \mathrm{~mL}$ capacity. Then, to the weighed amount with larvae $0.5 \%$ emulsion solutions of essential oils (in normal saline) of Picea abies (Linnaeus) H. Karsten., 1881 (limonene, bornyl acetate, $\delta$-cadinene, $\alpha$-muurolol, $\alpha$-cadinol and other), Cinnamomum verum J. Presl, 1825 ( $\alpha$-copaene, $\alpha$-bergamotene, $\alpha$-humulene, $\delta$-cadinene), Melaleuca alternifolia (Maiden \& Betche) Cheel, 1925 ( $\alpha$-terpinene, $\gamma$-terpinene, terpinen-4-ol), Citrus paradisi Macfadyen, 1830 (limonene), Rosmarinus officinalis Linnaeus, 1753 ( $\alpha$-pinene, linalool, piperitone), Citrus aurantiifolia (Christmann) Swingle, 1913 (1-methoxycyclohexene, corylone, 3-methyl-1,2-cyclopentanedione, 5,7-dimethoxycoumarin), Syzygium aromaticum (L.) Merrill \& Perry, 1939 (eugenol, eugenol acetate), Pterocarpus santalinus, Linnaeus filius, 1782 (cis- $\alpha$-santalol, cis- $\beta$-santalol), Pelargonium graveolens L'Héritier, 1789 ( $\beta$-citronellol, geraniol, citronellyl formate, 10-epi- $\gamma$-eudesmol), Eucalyptus globulus Labillardière, 1861 (1,8-cineole, a-pinene), Juniperus communis Linnaeus, 1753 ( $\alpha$-pinene, sabinene), Piper cubeba L.f., 1781 (citral, geraniol, citronellal), Calendula officinalis L., 1753 (flavonoids and carotenoids), Laurus nobilis L., 1753 (cineole, (-)-linalool, myrcene, $(+)$-limonene, $\alpha$ - and $\beta$-fellandrenes), Lavandula angustifolia Miller, 1768 (linalool, myrcene, $\alpha$ - and $\beta$-otsimen, $\gamma$-terpinene, $\alpha$-pinene, karyofillen, bergamoten) and Citrus sinensis (Linnaeus) Osbeck (pro. sp.) (limonene and other) were added. All experiments were performed in seven replications (KHEJFITs et al., 1994; VoJTKEVICH, 1999; Sellar, 2005). As the control, 0.9\% solution of
$\mathrm{NaCl}$ was used. "Farmakom" (Ukraine) - manufacturer of essential oils. Then the samples were put into the thermostat for $24 \mathrm{~h}$. For proving death of the larvae, we took into account two factors: immobility and decomposition of intestinal cells.

Eggs of $A$. suum were washed; for this purpose, the feces of $10 \mathrm{~g}$ mass were put into a glass cup and $100 \mathrm{~mL}$ of water was added. The eggs were washed several times until a clean sediment was obtained. The water-washed eggs were put into plastic test tubes $(1.5 \mathrm{~mL})$ by $0.1 \mathrm{~mL}$ in each (average 5-6 eggs). Then, $1 \mathrm{~mL}$ of emulsion solutions of essential oils were added, and also normal saline (in the control) in seven replications. The processing of the immature eggs with essential oils in $0.5 \%$ concentrations was made during $24 \mathrm{~h}$. Then the eggs of $A$. suum were washed with distilled water. The test tubes were put into the thermostat. The eggs were cultivated for 21 days at the temperature of $28^{\circ} \mathrm{C}$. Then, presense or absence of developed larvae was determined.

The statistical analysis of the results was performed through a set of Statistica 8.0 (StatSoft Inc., USA). The data in the Table are given in the form of mean \pm standard deviation $(x \pm S D)$. Reliability of differences between the control values and plant preparations are given according to ANOVA.

\section{Results and discussion}

For the most types of essential oils the mortality of noninvasive larvae $S$. papillosus $\mathrm{L}_{1-2}$ was significantly higher compared with infective stages of $S$. papillosus $\mathrm{L}_{3}$ and $H$. contortus $\mathrm{L}_{3}$ (Table 1). Exposure of the larvae to $0.5 \%$ essential oils from $P$. abies, L. nobilis, P. santalinus, P. graveolens, E. globulus, C. paradisi, C. sinensis, $C$. officinalis and $R$. officinalis for $24 \mathrm{~h}$ causes the death of $S$. papillosus and $H$. contortus larvae and eggs of $A$. suum.

A stronger effect was caused by $0.5 \%$ emulsion solution of essential oil of C. aurantiifolia. Around $8 \%$ of the third-stage larvae of $S$. papillosus were killed after $24 \mathrm{~h}$ exposure to this substance. Most susceptible were the firstsecond stage $S$. papillosus larvae: essential oil of lime in $0.5 \%$ decimated around $82 \%$ of larvae of these stages. The infective larvae of $H$. contortus were the most resistant to the essential oil of lime, no dead larvae were observed. Essential oil from M. alternifolia also exhibited no effect on third-stage larvae of $H$. contortus. However, a stronger effect was shown by $M$. alternifolia against the larvae of $S$. papillosus at different stages: first and second stage larvae died in $95 \%$ of cases, third-stage larvae - in $69 \%$.

The essential oil from $C$. verum was the most efficient against the nematode larvae. Larvae of $S$. papillosus of different stages, as well as third-stage $H$. contortus died in $100 \%$ of cases during $24 \mathrm{~h}$ exposure to $0.5 \%$ emulsion solution of cinnamon essential oil.

Oil from $S$. aromaticum also exerted a negative effect on different-stage nematode larvae: exposure of $S$. papillosus $\mathrm{L}_{1-3}$ and $H$. contortus to $0.5 \%$ emulsion solution of this oil resulted in killing all the larvae. 
Table 1. Mortality of larvae and eggs of parasitic nematodes (\%) during $24 \mathrm{~h}$ laboratory experiment $(\mathrm{x} \pm \mathrm{SD}, \mathrm{n}=7)$ exposed to essential oils

\begin{tabular}{|c|c|c|c|c|c|}
\hline Plant family & Plant species & $\begin{array}{c}\text { Nematode species and stage of } \\
\text { development }\end{array}$ & $\begin{array}{c}\text { Mortality of } \\
\text { nematode larvae in } \\
\text { plant oil solution, } \\
\%\end{array}$ & $\begin{array}{l}\text { Mortality of } \\
\text { nematode } \\
\text { larvae in } \\
\text { control, \% }\end{array}$ & $\mathrm{P}$ \\
\hline \multirow{4}{*}{ Pinaceae } & \multirow{4}{*}{$\begin{array}{c}\text { Picea abies (L.) H. Karsten., } \\
1881\end{array}$} & S. papillosus, $\mathrm{L}_{1-2}$ & $11.5 \pm 4.7$ & $8.4 \pm 3.0$ & - \\
\hline & & S. papillosus, $\mathrm{L}_{3}$ & $0.0 \pm 0.0$ & $0.0 \pm 0.0$ & - \\
\hline & & H. contortus, $\mathrm{L}_{3}$ & $0.0 \pm 0.0$ & $0.0 \pm 0.0$ & - \\
\hline & & A. suum, egg & $0.0 \pm 0.0$ & $0.0 \pm 0.0$ & - \\
\hline \multirow{4}{*}{ Cupressaceae } & \multirow{4}{*}{$\begin{array}{l}\text { Juniperus communis Linnaeus, } \\
1753\end{array}$} & S. papillosus, $\mathrm{L}_{1-2}$ & $12.9 \pm 4.5$ & $12.1 \pm 2.4$ & - \\
\hline & & S. papillosus, $\mathrm{L}_{3}$ & $0.0 \pm 0.0$ & $0.0 \pm 0.0$ & - \\
\hline & & H. contortus, $\mathrm{L}_{3}$ & $0.0 \pm 0.0$ & $0.0 \pm 0.0$ & - \\
\hline & & A. suum, egg & $0.0 \pm 0.0$ & $0.0 \pm 0.0$ & - \\
\hline \multirow{4}{*}{ Lauraceae } & \multirow{4}{*}{$\begin{array}{l}\text { Cinnamomum verum J. Presl, } \\
1825\end{array}$} & S. papillosus, $\mathrm{L}_{1-2}$ & $100.0 \pm 0.0$ & $8.4 \pm 3.0$ & $<0.001$ \\
\hline & & S. papillosus, $\mathrm{L}_{3}$ & $100.0 \pm 0.0$ & $0.0 \pm 0.0$ & $<0.001$ \\
\hline & & H. contortus, $\mathrm{L}_{3}$ & $100.0 \pm 0.0$ & $0.0 \pm 0.0$ & $<0.001$ \\
\hline & & A. suum, egg & $74.3 \pm 12.5$ & $0.0 \pm 0.0$ & $<0.001$ \\
\hline \multirow{4}{*}{ Lauraceae } & \multirow{4}{*}{ Laurus nobilis L., 1753} & S. papillosus, $\mathrm{L}_{1-2}$ & $13.2 \pm 2.5$ & $12.1 \pm 2.4$ & - \\
\hline & & S. papillosus, $\mathrm{L}_{3}$ & $0.0 \pm 0.0$ & $0.0 \pm 0.0$ & - \\
\hline & & H. contortus, $\mathrm{L}_{3}$ & $0.0 \pm 0.0$ & $0.0 \pm 0.0$ & - \\
\hline & & A. suum, egg & $0.0 \pm 0.0$ & $0.0 \pm 0.0$ & - \\
\hline \multirow{4}{*}{ Piperaceae } & \multirow{4}{*}{ Piper cubeba L.f., 1781} & S. papillosus, $\mathrm{L}_{1-2}$ & $77.3 \pm 3.5$ & $12.1 \pm 2.4$ & $<0.001$ \\
\hline & & S. papillosus, $\mathrm{L}_{3}$ & $0.0 \pm 0.0$ & $0.0 \pm 0.0$ & - \\
\hline & & H. contortus, $\mathrm{L}_{3}$ & $0.0 \pm 0.0$ & $0.0 \pm 0.0$ & - \\
\hline & & A. suum, egg & $0.0 \pm 0.0$ & $0.0 \pm 0.0$ & - \\
\hline \multirow{4}{*}{ Fabaceae } & \multirow{4}{*}{$\begin{array}{l}\text { Pterocarpus santalinus } \\
\text { Linnaeus filius, } 1782\end{array}$} & S. papillosus, $\mathrm{L}_{1-2}$ & $14.2 \pm 2.5$ & $12.1 \pm 2.4$ & - \\
\hline & & S. papillosus, $\mathrm{L}_{3}$ & $0.0 \pm 0.0$ & $0.0 \pm 0.0$ & - \\
\hline & & H. contortus, $\mathrm{L}_{3}$ & $0.0 \pm 0.0$ & $0.0 \pm 0.0$ & - \\
\hline & & A. suum, egg & $0.0 \pm 0.0$ & $0.0 \pm 0.0$ & - \\
\hline \multirow{4}{*}{ Geraniaceae } & \multirow{4}{*}{$\begin{array}{l}\text { Pelargonium graveolens } \\
\text { L'Héritier, } 1789\end{array}$} & S. papillosus, $\mathrm{L}_{1-2}$ & $10.6 \pm 2.8$ & $12.1 \pm 2.4$ & - \\
\hline & & S. papillosus, $\mathrm{L}_{3}$ & $0.0 \pm 0.0$ & $0.0 \pm 0.0$ & - \\
\hline & & H. contortus, $\mathrm{L}_{3}$ & $0.0 \pm 0.0$ & $0.0 \pm 0.0$ & - \\
\hline & & A. suum, egg & $0.0 \pm 0.0$ & $0.0 \pm 0.0$ & - \\
\hline \multirow{4}{*}{ Myrtaceae } & \multirow{4}{*}{$\begin{array}{c}\text { Melaleuca alternifolia (Maiden } \\
\text { \& Betche) Cheel, } 1925\end{array}$} & S. papillosus, $\mathrm{L}_{1-2}$ & $95.4 \pm 1.9$ & $8.4 \pm 3.0$ & $<0.001$ \\
\hline & & S. papillosus, $\mathrm{L}_{3}$ & $68.8 \pm 14.7$ & $0.0 \pm 0.0$ & $<0.001$ \\
\hline & & H. contortus, $\mathrm{L}_{3}$ & $0.0 \pm 0.0$ & $0.0 \pm 0.0$ & - \\
\hline & & A. suum, egg & $0.0 \pm 0.0$ & $0.0 \pm 0.0$ & - \\
\hline \multirow{4}{*}{ Myrtaceae } & \multirow{4}{*}{$\begin{array}{l}\text { Syzygium aromaticum (L.) } \\
\text { Merrill \& Perry, } 1939\end{array}$} & S. papillosus, $\mathrm{L}_{1-2}$ & $100.0 \pm 0.0$ & $8.6 \pm 2.3$ & $<0.001$ \\
\hline & & S. papillosus, $\mathrm{L}_{3}$ & $100.0 \pm 0.0$ & $0.0 \pm 0.0$ & $<0.001$ \\
\hline & & H. contortus, $\mathrm{L}_{3}$ & $100.0 \pm 0.0$ & $0.0 \pm 0.0$ & $<0.001$ \\
\hline & & A. suum, egg & $65.0 \pm 22.6$ & $0.0 \pm 0.0$ & $<0.001$ \\
\hline \multirow{4}{*}{ Myrtaceae } & \multirow{4}{*}{$\begin{array}{l}\text { Eucalyptus globulus } \\
\text { Labillardière, } 1861\end{array}$} & S. papillosus, $\mathrm{L}_{1-2}$ & $10.2 \pm 2.6$ & $12.1 \pm 2.4$ & - \\
\hline & & S. papillosus, $\mathrm{L}_{3}$ & $0.0 \pm 0.0$ & $0.0 \pm 0.0$ & - \\
\hline & & H. contortus, $\mathrm{L}_{3}$ & $0.0 \pm 0.0$ & $0.0 \pm 0.0$ & - \\
\hline & & A. suum, egg & $0.0 \pm 0.0$ & $0.0 \pm 0.0$ & - \\
\hline \multirow{4}{*}{ Rutaceae } & \multirow{4}{*}{$\begin{array}{c}\text { Citrus aurantiifolia } \\
\text { (Christmann) Swingle, } 1913\end{array}$} & S. papillosus, $\mathrm{L}_{1-2}$ & $82.4 \pm 4.0$ & $8.4 \pm 1.2$ & $<0.001$ \\
\hline & & S. papillosus, $\mathrm{L}_{3}$ & $7.7 \pm 6.7$ & $0.0 \pm 0.0$ & - \\
\hline & & H. contortus, $\mathrm{L}_{3}$ & $0.0 \pm 0.0$ & $0.0 \pm 0.0$ & - \\
\hline & & A. suum, egg & $0.0 \pm 0.0$ & $0.0 \pm 0.0$ & - \\
\hline
\end{tabular}


Table 1. Continued

\begin{tabular}{|c|c|c|c|c|c|}
\hline & & S. papillosus, $\mathrm{L}_{1-2}$ & $11.0 \pm 0.9$ & $10.6 \pm 2.7$ & - \\
\hline \multirow{3}{*}{ Rutaceae } & \multirow{3}{*}{$\begin{array}{c}\text { Citrus paradisi Macfadyen, } \\
1830\end{array}$} & S. papillosus, $\mathrm{L}_{3}$ & $0.0 \pm 0.0$ & $0.0 \pm 0.0$ & - \\
\hline & & H. contortus, $\mathrm{L}_{3}$ & $0.0 \pm 0.0$ & $0.0 \pm 0.0$ & - \\
\hline & & A. suum, egg & $0.0 \pm 0.0$ & $0.0 \pm 0.0$ & - \\
\hline \multirow{4}{*}{ Rutaceae } & \multirow{4}{*}{$\begin{array}{l}\text { Citrus sinensis (L.) Osbeck } \\
\text { (pro. sp.) }\end{array}$} & S. papillosus, $\mathrm{L}_{1-2}$ & $9.4 \pm 2.2$ & $12.1 \pm 2.4$ & - \\
\hline & & S. papillosus, $\mathrm{L}_{3}$ & $0.0 \pm 0.0$ & $0.0 \pm 0.0$ & - \\
\hline & & H. contortus, $\mathrm{L}_{3}$ & $0.0 \pm 0.0$ & $0.0 \pm 0.0$ & - \\
\hline & & A. suum, egg & $0.0 \pm 0.0$ & $0.0 \pm 0.0$ & - \\
\hline \multirow{4}{*}{ Asteraceae } & \multirow{4}{*}{ Calendula officinalis L., 1753} & S. papillosus, $\mathrm{L}_{1-2}$ & $9.8 \pm 1.7$ & $12.1 \pm 2.4$ & - \\
\hline & & S. papillosus, $\mathrm{L}_{3}$ & $0.0 \pm 0.0$ & $0.0 \pm 0.0$ & - \\
\hline & & H. contortus, $\mathrm{L}_{3}$ & $0.0 \pm 0.0$ & $0.0 \pm 0.0$ & - \\
\hline & & A. suum, egg & $0.0 \pm 0.0$ & $0.0 \pm 0.0$ & - \\
\hline \multirow{4}{*}{ Lamiaceae } & \multirow{4}{*}{$\begin{array}{l}\text { Lavandula angustifolia Miller, } \\
\qquad 1768\end{array}$} & S. papillosus, $\mathrm{L}_{1-2}$ & $50.0 \pm 4.4$ & $12.1 \pm 2.4$ & $<0.001$ \\
\hline & & S. papillosus, $\mathrm{L}_{3}$ & $0.0 \pm 0.0$ & $0.0 \pm 0.0$ & - \\
\hline & & H. contortus, $\mathrm{L}_{3}$ & $0.0 \pm 0.0$ & $0.0 \pm 0.0$ & - \\
\hline & & A. suum, egg & $0.0 \pm 0.0$ & $0.0 \pm 0.0$ & - \\
\hline \multirow{4}{*}{ Lamiaceae } & \multirow{4}{*}{$\begin{array}{l}\text { Rosmarinus officinalis } \\
\text { Linnaeus, } 1753\end{array}$} & S. papillosus, $\mathrm{L}_{1-2}$ & $9.4 \pm 0.9$ & $8.4 \pm 1.2$ & - \\
\hline & & S. papillosus, $\mathrm{L}_{3}$ & $0.0 \pm 0.0$ & $0.0 \pm 0.0$ & - \\
\hline & & H. contortus, $\mathrm{L}_{3}$ & $0.0 \pm 0.0$ & $0.0 \pm 0.0$ & - \\
\hline & & A. suum, egg & $0.0 \pm 0.0$ & $0.0 \pm 0.0$ & - \\
\hline
\end{tabular}

“_“, effect of essential oil from plant on vitality is absent; $<0.001$, reliability of differences between the control values and plant preparations according to ANOVA.

Use of the oil of L. angustifolia caused death to $50 \%$ of first- and second-stage larvae of S. papillosus. All the infective larvae were resistant to the effect of this plant preparation. Similar results were recorded for use of essential oil from $P$. cubeba: around $77 \%$ of non-infective larvae survived after $24 \mathrm{~h}$ exposure to emulsion solution of this essential oil.

Studies of the effect of essential oils on vitality of eggs of $A$. suum revealed the effect of two preparations: $C$. verum and $S$. aromaticum. Over $24 \mathrm{~h}$ exposure of immature eggs to $0.5 \%$ emulsion solution of essential oil from $C$. verum, we observed death of around $74 \%$ of eggs. Exposure to essential oil from $S$. aromaticum caused death to $65 \%$ of eggs of A. suum. Emulsion solutions of essential oils of the rest of the studied plants (Table 1) demonstrated no reliable effect on the development of eggs of $A$. suum.

Study of the level of the effect of essential oil on the vitality of parasites, including eggs and larvae of nematodes in vitro is relevant today. In the literature one can find data on the effect of essential oils from fruits and seeds of Schinus terebinthifolia Raddi on the vitality of larvae of mosquitoes Anopheles gambiae Giles, 1902, A. arabiensis Patton, 1905 and Culex quinquefasciatus Say, 1823, vectors of malaria and many dangerous viral diseases, in the environment (KWEKA et al., 2011). KWEKA et al. (2011) propose alternative insecticides with the use of this essential oil. Similar experiments were also undertaken by KwEKA et al. (2012).

The essential oil from Cinnamomum osmophloeum Kaneh was used against larvae of the mosquito $A$. gambiae. In spite of the growing resistance to insecticides of mosquitoes in the African countries, MdoE et al. (2014) investigated the essential oil of C. osmophloeum in order to find an alternative compound against the vectors of malaria.

The main components of the studied essential oil from $C$. verum are $\alpha$-bergamotene $(27.4 \%)$ and $\alpha$-copaene (23.1\%); in a lower amount it contains $\alpha$-humulene (6.2\%), $\delta$-cadinene $(6.0 \%)$, tetradecanol $(4.3 \%)$, viridiflorene (3.3\%), $\alpha$-muurolene $(2.7 \%)$, trans-cinnamyl acetate (2.4\%), germacrene D (2.1\%), epi- $\alpha$-bisabolol (2.1\%), spathulenol (2.0\%) and other components (JAYAPRAKASHA et al., 2002). Further studies on nematocidial activity of these components would be promising.

SiLva et al. (2010) also studied altenative methods of control of mosquitoes of the genus Aedes and its allies, such as Stegomyia, which transmit diseases such as dengue and yellow fever, by using essential oil of Brazilian pepper. Insecticidal properties of essential oils against parasites and pests of agriculture were also surveyed in the works by Pavela (2006), Boutoumi et al. (2009), SAmaraseKera et al. (2006), Clemente et al. (2008), Zoubiri et al. (2012), LAMARI et al. (2014), Essolakina et al. (2014), PARSIA et al. (2016), Kolani et al. (2016), Khoobdel et al. (2017), HenNia et al. (2019). No less relevant are the studies on the effect of essential oils on the vitality of Acari in the environment. CHEN et al. (2019) described the mortality level of Psoroptes ovis (Hering, 1838), mites, sheep parasites, exposed to four components of essential oil of plant origin (geraniol, eugenol, 1,8-cineole and carvacrol). 
Against Acari Sarcoptes scabiei (Linnaeus, 1758), parasites of agricultural animals, similar in vitro studies were undertaken by ZHOU et al. (2019). They indicate acaricidal effect of essential oil from Elsholtzia densa Benth. Against Tetranychus urticae Koch mites (Acari, Tetranychidae), agricultural pests of vegetables and decorative plants, ÇALMAşur et al. (2006) used vapours of essential oils from Micromeria fruticosa L., Nepeta racemosa L. and Origanum vulgare L. (Lamiaceae). Similar studies were performed by Neves et al. (2011), Attia et al. (2012), FAtemikia et al. (2017), and also DA CAmara et al. (2017). ReY-VAleirón et al. (2017) have proved the acaricidal effect of essential oils from Bursera graveolens (Kunth) Triana \& Planch. (Burseraceae) and Schinus molle Linnaeus, 1753 (Anacardiaceae).

Currently, the influence of essential oils on helminths of domestic animals and humans is being actively studied. SingH et al. (2009) studied the inhibitory effect of essential oils of Allium sativum L. and Piper longum L., JEYATHILAKAN et al. (2010) - of Cymbopogon nardus L. (citronella) and Azadirachta indica A. Juss. (Neem) on Fasciola gigantica Cobbold, 1858. Anthelmintic effect of Mentha spp. essential oils on Echinococcus granulosus (Batsch, 1786) is described in the study by MAGGIORE et al. (2011). There are studies on the effect of essential oils on vitality of nematodes. Therefore, OlounLadé et al. (2011) studied the in vitro anthelmintic activity of the essential oils of Zanthoxylum zanthoxyloides (Lam.) Zepern. \& Timler and Newbouldia laevis Seem. against Strongyloides ratti Sandground, 1925. KATIKI et al. (2011) studied the anthelmintic activity of essential oils from Cymbopogon martini (Roxb.) Wats., C. schoenanthus Spreng. and Mentha piperita L. The experiments were performed on the eggs and larvae of nematodes $H$. contortus and Trichostrogylus spp. They revealed that essential oil from $C$. schoenanthus could be used against nematodes. Similar experiments were undertaken by SAHA and LACHANCE (2019) and Macedo et al. (2019). Their results suggest that EOs from the genus Cymbopogon can be interesting candidates for nematode control in cattle.

The results of all these studies partly coinside with our experiments regarding the effect of a variety of essential oils against parasitic organisms, including larvae of $H$. contortus and S. papillosus, and eggs of A. suum.

\section{Conclusion}

In vitro conditions revealed perspectives for further use of essential oils of Cinnamomum verum, Piper cubeba, Melaleuca alternifolia, Syzygium aromaticum, Citrus aurantiifolia, and Lavandula angustifolia against parasitic nematodes of agricultural animals. The most notable nematocidial properties were exerted by the emulsion solutions of essential oils from Cinnamomum verum and Syzygium aromaticum. Exposure of different stages of nematode larvae of ruminants $\left(S\right.$. papillosus $\mathrm{L}_{1-3}$ and $H$. contortus $\mathrm{L}_{3}$ ) to these oils was followed by the death of $100 \%$ of them. The results of the experiments can be used for the development of complex methods of protecting agricultural anaimals against the commonest species of nematods.

\section{Acknowledgement}

This work was supported by the Ministry of Education and Science of Ukraine (grant 0120U102384).

\section{References}

Attia, S., Grissa, K.L., Ghrabi, Z.G., MailleuX, A.C., Lognay, G., Hance, T., 2012. Acaricidal activity of 31 essential oils extracted from plants collected in Tunisia. Journal of Essential Oil Research, 24: 279-288. https:// doi.org/10.1080/10412905.2012.676777

Boutoumi, H., Moulay, S., Khodja, M., 2009. Essential oil from Ruta montana L. (Rutaceae) chemical composition, insecticidal and larvicidal activities. Journal of Essential Oil Bearing Plants, 12: 714-721. https://doi.org/10.1080/ 0972060x.2009.10643780

Boyko, A.A., BRYGADYRENKo, V.V., 2016. Influence of water infusion of medicinal plants on larvae of Strongyloides papillosus (Nematoda, Strongyloididae). Visnyk of Dnipropetrovsk University, Biology, Ecology, 24: 519525. https://doi.org/10.15421/011670

Boyko, O.O., Brygadyrenko, V.V., 2018. The impact of certain flavourings and preservatives on the survivability of larvae of nematodes of Ruminantia. Regulatory Mechanisms in Biosystems, 9: 118-123. https://doi. org/10.15421/021817

Boyko, O.O., Brygadyrenko, V.V., 2019a. The viability of Haemonchus contortus (Nematoda, Strongylida) and Strongyloides papillosus (Nematoda, Rhabditida) larvae exposed to concentrations of flavourings and source materials approved for use in and on foods. Vestnik Zoologii, 53: 433-442. https://doi.org/10.2478/vzoo2019-0039

Boyko, O.O., Brygadyrenko, V.V., 2019b. Nematocidial activity of aqueous solutions of plants of the families Cupressaceae, Rosaceae, Asteraceae, Fabaceae, Cannabaceae and Apiaceae. Biosystems Diversity, 27: 227-232. https://doi.org/10.15421/011931

Çalmaşur, Ö., Aslan, İ., ŞAhin, F., 2006. Insecticidal and acaricidal effect of three Lamiaceae plant essential oils against Tetranychus urticae Koch and Bemisia tabaci Genn. Industrial Crops and Products, 23: 140-146. https://doi.org/10.1016/j.indcrop.2005.05.003

Chen, Z., van Mol, W., Vanhecke, M., Duchateau, L., Claerebout, E., 2019. Acaricidal activity of plant-derived essential oil components against Psoroptes ovis in vitro and in vivo. Parasites and Vectors, 12: 425. https://doi. org/10.1186/s13071-019-3654-x

Clemente, S.V., Mareggiani, G., Juárez, B.E., Mendiondo, M.E., van Baren, C.M., Lira, P.D.L., Ferraro, G.E., 2008. Insecticidal activity of the essential oil and extracts of Gutierrezia mandonii and G. repens (Asteraceae) growing in Argentina. Journal of Essential Oil Research, 20: $276-278$.

https://doi.org/10.1080/10412905.2008.9700011 
Da Camara, C.A.G., de Moraes, M.M., De Melo, J.P.R., DA Silva, M.M.C., 2017. Chemical composition and acaricidal activity of essential oils from Croton rhamnifolioides Pax and Hoffm. In different regions of a Caatinga Biome in Northeastern Brazil. Journal of Essential Oil Bearing Plants, 20: 1434-1449. https://doi. org/10.1080/0972060x.2017.1416677

Essolakina, B.M., Koffi, K., Nenonene, A.Y., Wiyao, P., Komlan, A.P., Bakouma, L., Abouwaliou, N.N., Christine, R., Komla, S., 2014. Insecticidal activities of Ocimum canum Sims essential oil on termites Macrotermes subhyalinus Rambur (Isoptera: Termitidae). Journal of Essential Oil Bearing Plants, 17: 726-733. https://doi.org/10.1080/0972060x.2014.929045

Fatemikia, S., Abbasipour, H., Saeedizadeh, A., 2017. Phytochemical and acaricidal study of the galbanum, Ferula gumosa Boiss. (Apiaceae) essential oil against Tetranychus urticae Koch (Tetranychidae). Journal of Essential Oil Bearing Plants, 20: 185-195. https://doi.org/10.1080/0972060x.2016.1257957

Hennia, A., Nemmiche, S., Dandlen, S., Miguel, M.G., 2019. Myrtus communis essential oils: insecticidal, antioxidant and antimicrobial activities: a review. Journal of Essential Oil Research, 31: 487-545. https://doi.org/10 .1080/10412905.2019.1611672

Jayaprakasha, G.K., RaO, L.J., Sakariah, K.K., 2002. Chemical composition of volatile oil from Cinnamomum zeylanicum buds. Zeitschrift Für Naturforschung C, 57: 990-993.

Jeyathilakan, N., Murali, K., Anandaraj, A., Latha B.R., Abdul Basith, S., 2010. Anthelmintic activity of essential oils of Cymbopogan nardus and Azadirachta indica on Fasciola gigantica. Tamilnadu Journal of Veterinary and Animal Sciences, 6: 204-209.

Katiki, L.M., Chagas, A.C.S., Bizzo, H.R., Ferreira, J.F.S., Amarante, A.F.T., 2011. Anthelmintic activity of Cymbopogon martinii, Cymbopogon schoenanthus and Mentha piperita essential oils evaluated in four different in vitro tests. Veterinary Parasitology, 183: 103-108. https://doi.org/10.1016/j.vetpar.2011.07.001

KHeJfits, L.A., Dashunin, V.M., 1994. Dushistye veshhestva $i$ drugie produkty dlya parfyumerii [Perfumes and other perfumery products]. Moscow: Chemistry. $256 \mathrm{p}$.

Khoobdel, M., Ahsaei, S.M., Farzaneh, M., 2017. Insecticidal activity of polycaprolactone nanocapsules loaded with Rosmarinus officinalis essential oil in Tribolium castaneum (Herbst). Entomological Research, 47: 175-184. https://doi.org/10.1111/1748-5967.12212

Kolani, L., Sanda, K., AgboKa, K., Mawussi, G., Koba, K., DJOUAKA, R., 2016. Investigation of insecticidal activity of blend of essential oil of Cymbopogon schoenanthus and neem oil on Plutella xylostella (Lepidoptera: Plutellidae). Journal of Essential Oil Bearing Plants, 19: 1478-1486. https://doi.org/10.1080/0972060x.2016.1221742

Kweka, E.J., Nyindo, M., Mosha, F., Silva, A.G., 2011. Insecticidal activity of the essential oil from fruits and seeds of Schinus terebinthifolia Raddi against African malaria vectors. Parasites and Vectors, 4: 129. https:// doi.org/10.1186/1756-3305-4-129

Kweka, E.J., Senthilkumar, A., Venkatesalu, V., 2012. Toxicity of essential oil from Indian borage on the larvae of the African malaria vector mosquito, Anopheles gambiae. Parasites and Vectors, 5: 277. https://doi. org/10.1186/1756-3305-5-277

Lamari, A., Teyeb, H., Cheikh, H.B., Douki, W., NefFati, M., 2014. Chemical composition and insecticidal activity of essential oil of Salvia officinalis L. cultivated in Tunisia. Journal of Essential Oil Bearing Plants, 17: 506-512. https://doi.org/10.1080/0972060x.2013.764197

Macedo, I.T.F., de Oliveira, L.M.B., ANDrÉ, W.P.P., DE Araújo Filho, J.V., dos Santos, J.M.L., Rondon, F.C.M., Ribeiro, W.L.C., CamurÇa-Vasconcelos, A.L.F., de Oliveira, E.F., Beserra de Paula, H.C., Bevilaqua, C.M.L., 2019. Anthelmintic effect of Cymbopogon citratus essential oil and its nanoemulsion on sheep gastrointestinal nematodes. Revista Brasileira de Parasitologia Veterinária, 28: 522-527. https://doi. org/10.1590/s1984-29612019065

Maggiore, M.A., Albanese, A.A., Gende, L.B., Eguaras, M.J., Denegri, G.M., Elissondo, M.C., 2011. Anthelmintic effect of Mentha spp. essential oils on Echinococcus granulosus protoscoleces and metacestodes. Parasitology Research, 110: 1103-1112. doi:10.1007/s00436-011-2595-x

Martynov, V.O., Hladkyi, O.Y., Kolombar, T.M., BRYGADYRENKo, V.V., 2019a. Impact of essential oil from plants on migratory activity of Sitophilus granarius and Tenebrio molitor. Regulatory Mechanisms in Biosystems, 10: 359-371. doi: 10.15421/021955

Martynov, V.O., Titov, O.G., Kolombar, T.M., BrygadyrenKo, V.V., 2019b. Influence of essential oils of plants on the migration activity of Tribolium confusum (Coleoptera, Tenebrionidae). Biosystems Diversity, 27: 177-185. https://doi.org/10.15421/011924

Mdoe, F.P., Cheng, S.S., Msangi, S., Nkwengulila, G., Chang, S.T., Kweka, E.J., 2014. Activity of Cinnamomum osmophloeum leaf essential oil against Anopheles gambiae s.s. Parasites and Vectors, 7: 209. https://doi.org/10.1186/1756-3305-7-209

Neves, I.I.A., DA Camara, C.A.G., De Oliviera, J.C.S., DE Almeida, A.V., 2011. Acaricidal activity and essential oil composition of Petiveria alliacea L. from Pernambuco (Northeast Brazil). Journal of Essential Oil Research, 23: 23-26. https://doi.org/10.1080/10412905.2011.9700426

Olounladé P.A., Azando E.V.B., Hounzangbé-Adoté, M.S., Ha, T.B.T., Leroy, E., Moulis, C., Fabre, N., Magnaval, J.F., Hoste, H., Valentin, A., 2011. In vitro anthelmintic activity of the essential oils of Zanthoxylum zanthoxyloides and Newbouldia laevis against Strongyloides ratti. Parasitology Research, 110: 1427-1433. https://doi.org/10.1007/s00436-011-2645-4

Palchykov, V.A., ZaZharskyi, V.V., Brygadyrenko, V.V., Davydenko, P.O., Kulishenko, O.M., BoroviK, I.V., Chumak, V., Kryvaya, A., Boyko, O.O., 2019. Bactericidal, protistocidal, nematodicidal properties and chemical composition of ethanol extract of Punica granatum peel. Biosystems Diversity, 27: 300-306. https://doi.org/10.15421/011939

Parsia Aref, S., Valizadegan, O., Farashiani, M.E., 2016. The insecticidal effect of essential oil of Eucalyptus floribundi against two major stored product insect pests 
Rhyzopertha dominica (F.) and Oryzaephilus surinamensis (L.). Journal of Essential Oil Bearing Plants, 19: 820 831. https://doi.org/10.1080/0972060x.2014.958569

Pavela, R., 2006. Insecticidal activity of essential oils against cabbage aphid Brevicoryne brassicae. Journal of Essential Oil Bearing Plants, 9: 99-106. https://doi.org/ 10.1080/0972060x.2006.10643479

Rey-Valeirón, C., Guzmán, L., SaA, L.R., López-Vargas, J., Valarezo, E., 2017. Acaricidal activity of essential oils of Bursera graveolens (Kunth) Triana \& Planch and Schinus molle L. on unengorged larvae of cattle tick Rhipicephalus (Boophilus) microplus (Acari: Ixodidae). Journal of Essential Oil Research, 29: 344-350. https:// doi.org/10.1080/10412905.2016.1278405

Saha, S., Lachance, S., 2019. Effect of essential oils on cattle gastrointestinal nematodes assessed by egg hatch, larval migration and mortality testing. Journal of Helminthology, 94: e111. https://doi.org/10.1017/ s0022149x19001081

Samarasekera, R., Kalhari, K.S., Weerasinghe, I.S., 2006. Insecticidal activity of essential oils of Ceylon Cinnamomum and Cymbopogon species against Musca domestica. Journal of Essential Oil Research, 18: 352 354. https://doi.org/10.1080/10412905.2006.9699110

SELlar, V., 2005. Entsiklopediya efirnykh masel [Encyclopedia of essential oils]. Moscow: Fair-Press. 400 p.

Silva, A.G., Almeida, D.L., Ronchi, S.N., Bento, A.C., Scherer, R., Ramos, A.C., Cruz, Z.M., 2010. The essential oil of Brazilian pepper, Schinus terebinthifolia Raddi in larval control of Stegomyia aegypti (Linnaeus, 1762). Parasites and Vectors, 3: 79. https://doi. org/10.1186/1756-3305-3-79

Singh, T.U., Kumar, D., Tandan, S.K., Mishra, S.K., 2009. Inhibitory effect of essential oils of Allium sativum and Piper longum on spontaneous muscular activity of liver fluke, Fasciola gigantica. Experimental Parasitology, 123 : 302-308. https://doi.org/10.1016/j.exppara.2009.08.002

VAN WYK, J.A., MAYHEW, E., 2013. Morphological identification of parasitic nematode infective larvae of small ruminants and cattle: A practical lab guide. The Onderstepoort Journal of Veterinary Research, 80: 1-14. doi:10.4102/ojvr.v80i1.539

Van Wyk, J.A., Cabaret, J., Michael, L.M., 2004. Morphological identification of nematode larvae of small ruminants and cattle simplified. Veterinary Parasitology, 119: 277-306. https://doi.org/10.1016/j. vetpar.2003.11.012

VojtKeVICH, S.A., 1999. Efirnye masla dlya parfyumerii $i$ aromaterapii [Essential oils for perfumes and aromatherapy]. Moscow: Pishchevaya promishlennost'. $329 \mathrm{p}$.

ZAJAC, A.M., 2011. Veterinary clinical parasitology. 8th ed. London: John Wiley and Sons. 368 p.

Zazharska, N., Boyko, O., Brygadyrenko, V., 2018. Infuence of diet on the productivity and characteristics of goat milk. Indian Journal of Animal Research, 52: 711717. doi: 10.18805/ijar.v0iOF.6826

Zhou, Y., Liao, F., Weng, J., Mo, Q., Xu, R., Zhang, Y., Ren, Z., Zhong, Z., Zuo, Z., Peng, G., Deng, J., Tang, C., Hu, Y., 2019. Composition and acaricidal activity of essential oil from Elsholtzia densa Benth against Sarcoptes scabiei mites in vitro. Veterinární Medicína, 64: 178-183. https:// doi.org/10.17221/20/2018-vetmed

Zoubiri, S., BaAliouamer, A., 2012. Chemical composition and insecticidal properties of Lantana camara L. leaf essential oils from Algeria. Journal of Essential Oil Research, 24: 377-383. https://doi.org/10.1080/1041290 5.2012 .692910

Received June 7, 2020

Accepted August 7, 2020 